\title{
Pengaruh Pemberian Fermentasi Tepung Kulit Pisang Jantan dengan Menggunakan Neurospora crassa terhadap Deposisi Lemak Ayam Broiler
}

\section{The Effect of Fermented Banana Peel Flour Using Neurospora crassa on Broiler Chicken Fat Deposition}

\author{
M. Dorisandi, L. Saputro, S. H. Jatmiko dan Y. Fenita \\ Jurusan Peternakan, Fakultas Pertanian, Universitas Bengkulu \\ Jalan W.R. Supratman Kandang Limun Bengkulu 38371A \\ Email : yosifenita15@gmail.com
}

\begin{abstract}
ABTRACT
This study used 80 broiler chickens. The stages of the research started from the preparation of the cage, the manufacture of fermentation of banana peel flour, chicken maintenance for 36 days, and slaughering. This study consisted of 5 treatments and 4 replications using a complete randomized design (RAL), which was each consisted of 4 broiler chickens. The treatments were PO: control, P1: 2.5\% fermented banana peel flour, P2: 5\% fermented banana peel flour, P3: 7.5\% fermented banana peel flour, P4: 10\% fermented flour banana peel. The parameters to be measured were ration consumption, weight, weight percentage of carcass, fat (percentage of abdominal fat, percentage of gizzard fat, percentage of intestinal fat, percentage of fat of neck, percentage of fat of thigh, and percentage of internal organs). Based on analysis of variance, it showed that fermented banana peel flour (KPF) using Neurospora crassa did not lose weight but reduced abdominal fat, gizzard fat, neck fat, intestinal fat, femoral fat up to $10 \%$ of the flour.
\end{abstract}

Key words: Banana peel, fat deposition, broiler chicken, Neurospora crassa

\begin{abstract}
ABTRAK
Penelitian ini menggunakan ayam broiler sebanyak 80 ekor. Tahapan penelitian dimulai dari persiapan kandang, pembuatan fermentasi tepung kulit pisang jantan, pemeliharaan ayam selama 36 hari, dan pemotongan. Penelitian ini terdiri dari 5 perlakuan dan 4 ulangan dengan menggunakan rancangan acak lengkap (RAL), yang setiap ulangan terdapat 4 ekor ayam broiler. Perlakuan tersebut yaitu, PO: kontrol, P1: 2,5\%, fermentasi tepung kulit pisang, P2: 5\% fermentasi tepung kulit pisang, P3= 7,5\% fermentasi tepung kulit pisang, P4: $10 \%$ fermentasi tepung kulit pisang. Paramater yang akan diukur pada penelitian ini adalah konsumsi ransum, berat badan, persentase berat karkas, perlemakan (persentase lemak abdomen, persentase lemak gizzard, persentase lemak penggantung usus, persentase lemak leher, persentase lemak paha, dan persentase organ dalam). Berdasarkan hasil analisis sidik ragam menunjukkan bahwa pemberian tepung kulit pisang fermentasi (KPF) dengan menggunakan Neurospora crassa tidak menurunkan berat badan tetapi mengurangi lemak abdomen, lemak gizzard, lemak leher, lemak penggantung usus, lemak paha hingga level $10 \%$.
\end{abstract}

Kata kunci: Kulit pisang, deposisi lemak, ayam broiler, Neurospora crassa

\section{PENDAHULUAN}

Kulit pisang merupakan salah satu

limbah pertanian yang belum digunakan

secara maksimal. Potensi limbah kulit

pisang yang terbuang sia-sia perlu pemanfaatan yang berkelanjutan.

Penelitian terhadap pemanfaatan limbah

kulit pisang tersebut sebagai pakan ternak ayam broiler serta pengaruh pemberian fermentasi tepung kulit pisang jantan dengan Neurospora crassa terhadap deposisi lemak ayam broiler.

Kulit pisang memiliki kandungan zat-zat yang dibutuhkan unggas yaitu protein kasar 9,2 \%, lemak kasar 15,46 \%, serat kasar 14,15\%, dan BETN 49,12\% (Mirnawati, 2001). Selain itu, kulit pisang 
memiliki kandungan nutrisi yang cukup tinggi terutama provitamin A, yaitu betakaroten sebanyak 5,127 mg/100 g. Hal ini menunjukan limbah kulit pisang memiliki potensi untuk mengganti sebagian betakarotein jagung yang memiliki betakaroten 3,3 mg/100 g (Rika, 2012). Betakaroten merupakan provitamin A yang akan diubah menjadi vitamin A di mukosa usus halus dan diserap dalam bentuk vitamin $\mathrm{A}$, sehingga peningkatan konsumsi beta-karoten juga dapat menghasilkan produk tinggi vitamin A. Hasil penelitian Rika (2012) menunjukan bahwa betakaroten dalam tepung kulit pisang mampu mensubstitusi $20 \%$ beta-karoten dalam jagung dan dapat meningkatkan vitamin A kuning telur. Beta-karoten juga dapat berfungsi sebagai antioksidan (Elvien, 2010), sehingga dapat mencegah oksidasi asam lemak tidak jenuh dan menghasilkan produk komposisi asam lemak yang baik.

$$
\text { Kulit pisang mengandung }
$$

karbohidrat terutama bahan ekstrak tanpa nitrogen sebesar 66,20\% (Heruwatno et al., 1993) sehingga dapat digunakan untuk mengganti sebagian jagung atau dedak dalam ransum. Hasil analisis (Susilowati, 1997) diperoleh komposisi nutrisi sebagai berikut; BK: 12,6\%, BO: 80,36\%, PK: 8,36\%, Gula Reduksi: 42,34\%, dan Gula Terlarut: $5,41 \%$. Dilihat dari jumlah produksi yang melimpah dan tidak termanfaatkan serta kandungan gizinya yang kaya provitamin A, yaitu betakaroten, maka kulit pisang sangat potensial untuk dimanfaatkan menjadi pakan ternak unggas. Namun, kulit pisang tidak dapat diberikan secara langsung, karena kandungan protein kasarnya rendah, serat kasarnya tinggi serta mudah membusuk dan terdapat zat nutrisi yaitu tannin, sehingga perlu dilakukan pengolahan dengan cara di fermentasi lalu dibuat tepung. Fermentasi ini menggunakan Neurospora crassa.

Neurospora crassa merupakan salah satu spesies yang masuk kedalam Genus Neurospora, Family Sordariacea, Ordo Sordariales, Class Ascomycetes, Divisio Ascomycota, dan Kingdom Fungi. Neurospora crassa merupakan penghasil beta-karoten tertinggi dibandingkan dengan kapang karatogenik yang lainnya yang diisolasi dari tongkol jagung (Nuraini et al., 2008). Selain itu, kapang Neurospora crassa dapat meningkatkan kandungan protein dan menurunkan serat kasar. Pernyataan ini diperkuat oleh penelitian Fenita et al. (2010) bahwa penggunaan Neurospora crassa pada lumpur sawit telah difermentasi, kandungan protein kasar lumpur sawit meningkat dari $13,57 \%$ menjadi $23,54 \%$. Hasil penelitian Sinurat et al. (1999) menemukan fermentasi dengan menggunakan kapang Aspergillus niger mampu meningkatkan protein kasarnya dari $11,94 \%$ menjadi $22,6 \%$, menurunkan serat kasarnya dari $62,8 \%$ menjadi $52,12 \%$. Santoso et al. (1995; 2001) menemukan bahwa suplementasi mikroorganisme efektif mampu menurunkan deposisi lemak pada broiler. Sahin dan Yardimci (2009) menemukan bahwa suplementasi kefir dapat menurunkan lemak abdominal pada angsa. Neurospora crassa ini merupakan kapang yang berperan dalam pembuatan 
oncom, kapang juga dapat berperan sebagai penghambat laju pertumbuhan lemak yang diberikan melalui pakan.

\section{MATERI DAN METODE}

\section{Fermentasi Kulit Pisang}

Langkah-langkah dalam proses permentasi yaitu (Nuraini, 2006 dan Fenita et al, 2010 yang telah dimodifikasi) :

1. Pemilihan kulit pisang jantan, digunakan yang sudah matang, ditandai dengan kulit pisang yang berwarna kuning.

2. Dicuci dengan air bersih lalu dipotong $5 \mathrm{~cm}$.

3. Kulit pisang yang sudah dipotong, dijemur di bawah sinar matahari selama 4 hari (sampai kering).

4. Digiling (tepung) dengan menggunakan alat penggiling (hammer mill) lalu diayak dengan menggunakan ayakan saringan plastik.
5. Dikukus dengan menggunakan alat pengukus, selama 15 menit dihitung setelah air mendidih.

6. Kulit pisang yanng sudah dikukus kemudian diangin-aginkan.

7. Dicampur dengan kapang neurospora crassa hingga homogen, sebanyak $9 \%$ untuk setiap $1 \mathrm{~kg}$ kulit pisang dan penambahan air dan mineral, (NH4)2SO4 (3,6\%), Urea (2\%), NaH2PO4 (0,75\%), $\mathrm{MgSO} 4$ (0,25\%).

8. Kulit pisang yang disimpan pada suhu kamar selama 5-7 hari. Kulit pisang yang sudah difermantasi kemudian dijemur lagi selama 1 jam.

9. Digiling sebelum dicampur dengan bahan pakan lainnya

\section{Persiapan Ransum}

Komposisi dan nutrisi bahan penyusun ransum yang mengandung kulit pisang fermentasi (KPF) yang berasal dari pisang Jantan untuk broiler dapat dilihat pada Tabel 1 berikut.

Tabel 1. Kandungan nutrisi bahan penyusun ransum

\begin{tabular}{lcccccc}
\hline \multicolumn{1}{c}{ Bahan pakan } & $\begin{array}{c}\text { Protein } \\
(\%)\end{array}$ & $\begin{array}{c}\text { Energi } \\
(\mathrm{Kkal} / \mathrm{kg})\end{array}$ & SK $(\%)$ & $\begin{array}{c}\text { Lemak } \\
(\%)\end{array}$ & $\begin{array}{c}\mathrm{Ca} \\
(\%)\end{array}$ & $\mathrm{P}(\%)$ \\
\hline Jagung giling & 8.9 & 3340 & 2.82 & 3.9 & 0.06 & 0.29 \\
Konsentrat broiler & 41.5 & 2800 & 5 & 6 & 2.72 & 1.45 \\
Dedak halus & 10.45 & 1856.49 & 19.34 & 9.78 & 0.92 & 0.29 \\
KPF & 7.012 & 2795 & 8.79 & 4.36 & 0.89 & 0.29 \\
Mineral mix & 0 & 0 & 0 & 0 & 32 & 10 \\
Top mix & 0 & 0 & 0 & 0 & 0 & 0 \\
Minyak & 0 & 9800 & 0 & 0 & 0 & 0 \\
\hline
\end{tabular}

Keterangan : Fenita et al. (2013). Konsentrat broiler (PT Jafpa Comfeed). Hasil analisis proksimat di Laboratorium Ilmu dan Teknologi Pakan. IPB, Bogor (2014). Label mineral mix. Label Top Mix (Wahyu , 2004). 
Adapun bahan KPF yang selama penelitian disajikan pada Tabel 2. terkandung dalam ransum untuk broiler

Tabel 2. Komposisi ransum penelitian

\begin{tabular}{lccccc}
\hline & \multicolumn{5}{c}{ Ransum perlakuan } \\
Bahan pakan & P0 & P1 & P2 & P3 & P4 \\
\hline Jagung giling (\%) & 49.5 & 48.5 & 43 & 38 & 33 \\
Konsentrat broiler (\%) & 40 & 39 & 39.5 & 39,5 & 39.5 \\
Dedak halus (\%) & 8 & 5 & 5 & 5 & 5 \\
KPF (\%) & 0 & 5 & 10 & 15 & 20 \\
Mineral mix (\%) & 1 & 1 & 1 & 1 & 1 \\
Top mix (\%) & 0.5 & 0.5 & 0,5 & 0.5 & 0.5 \\
Minyak (\%) & 1 & 1 & 1 & 1 & 1 \\
$\quad$ Total (\%) & 100 & 100 & 100 & 100 & 100 \\
\hline
\end{tabular}

Kandungan nutrisi ransum untuk broiler selama penelitian disajikan pada Tabel 3.

Tabel 3. Kandungan nutrisi ransum penelitian

\begin{tabular}{lccccc}
\hline Kandungan Nutrien & P0 & P1 & P2 & P3 & P4 \\
\hline Protein Kasar (\%) & 21.84 & 21.380 & 21.45 & 21.37 & 21.28 \\
ME (Kkal/kg) & 3.020 & 3.042 & 3.013 & 21.985 & 2.958 \\
Serat Kasar (\%) & 4.94 & 4.72 & 5.03 & 5.33 & 5.63 \\
Lemak (\%) & 5.11 & 4.94 & 4.97 & 5.00 & 5.02 \\
Ca (\%) & 1.51 & 1.50 & 1.56 & 1.60 & 1.64 \\
Pospor (\%) & 0.85 & 0.83 & 0.84 & 0.84 & 0.84 \\
\hline
\end{tabular}

\section{Persiapan Ternak}

DOC yang baru datang diberi air minum gula untuk menghilangkan stress perjalanan. Sebanyak 80 ekor ayam broiler ditempatkan secara acak ke dalam 20 petak kandang, setiap kandang berisi 4 ekor ayam broiler. Ayam broiler dipelihara dalam kandang litter selama 35 hari. Pemeliharaan broiler dipelihara sesuai dengan ketentuan pemeliharaan yang berlaku. Jumlah ransum yang dikonsumsi, konversi pakan, dan pertambahan berat badan diukur setiap minggu. Untuk mencegah timbulnya penyakit ND, maka diberikan vaksin ND pada saat broiler berumur 4 hari melalui tetes mata dan pada saat broiler berumur 21 hari melalui air minum, untuk vaksinasi gumboro dilakukan pada umur 10 hari dan 18 hari.

\section{Rancangan Percobaan}

Penelitian ini menggunakan rancangan acak lengkap (RAL), dengan 5 perlakuan dan 4 ulangan setiap ulangan terdiri dari 4 ekor ayam, 5 perlakuan tersebut adalah sebagai berikut:

P0 : Tanpa fermentasi tepung kulit pisang dalam ransum

P1 : Menggunakan 2,5 \% fermentasi tepung kulit pisang

P2 : Mengggunakan $5 \%$ fermentasi tepung kulit pisang

P3 : Menggunakan 7,5 \% fermentasi tepung kulit pisang 
P4 : Menggunakan $10 \%$ fermentasi tepung kulit pisang

\section{Pemotongan Ayam Sampling}

Pada umur 36 hari, satu ekor ayam broiler diambil secara acak terus disembelih. Sebelum penyembelihan, ayam dipuasakan selama 12 jam. Dilakukan penimbangan terhadap berat badan, berat masing-masing organ dalam, kadar lemak karkas, kadar kolesterol karkas dan lemak abdomen, lemak gizzard, fatty liver score (FLS), lemak penggantung usus, lemak sartorial (paha) dan lemak leher.

\section{Variabel yang Diamati}

\section{Lemak Abdomen}

Lemak abdomen diperoleh dengan menimbang lemak yang menempel pada rongga perut dari dasar kloaka sampai gizzard, kemudian lemak tersebut dipersentasekan dengan berat badan akhir. Adapun rumus untuk menghitung persentase lemak abdomen adalah sebagai berikut :

Lemak abdomen (\%)

$=\frac{\text { berat lemak abdomen }}{\text { berat badan }} \times 100 \%$

\section{Lemak Gizzard}

Lemak gizzard diproleh dengan menimbang lemak yang menempel pada gizard, lalu lemak dipresentasekan dengan berat badan akhir. Adapun rumus untuk menghitung presentase lemak gizzard adalah :

$$
\begin{gathered}
\text { Lemak gizzard }(\%)= \\
\frac{\text { erat lemak gizzard }}{\text { berat badan }} \times 100 \%
\end{gathered}
$$

\section{Fatty Liver Score (FLS)}

Fatty Liver Score (FLS) diperoleh dengan membandingkan warna hati dengan warna standar 1-5. Rumusnya adalah :

Fatty liver score (FLS)

$$
=\frac{\text { jumla } h \text { fatty liver score setiap perlakuan }}{\text { jumla } h \text { perlakuan dalam setiap ulang an }}
$$

\section{Lemak Penggantung Usus}

Lemak penggantung usus adalah lemak yang berada di sekitar usus dan penggantung usus. Rumus untuk menghitung presentase lemak penggantunng usus adalah sebagai berikut :

$$
\begin{aligned}
& \text { Lemak penggantung usus }(\%)= \\
& \frac{\text { berat lema } k \text { penggantung usus }}{\text { berat badan }} \times 100 \%
\end{aligned}
$$

\section{Lemak Leher}

Lemak leher adalah lemak yang menempel pada bagian leher, lalu lemak ini dipersentasekan dengan berat badan akhir. Adapun rumus untuk mennghitung presentase dari lemak leher adalah sebagai berikut :

$$
\begin{gathered}
\text { Lemak leher }(\%)= \\
\frac{\text { berat lemak leher }}{\text { berat badan }} \times 100 \%
\end{gathered}
$$

\section{Lemak Sartorial (Paha)}

$\begin{array}{rrr}\text { Adapun } & \text { rumus } & \text { untuk } \\ \text { menghitungnya } & \text { adalah } & \text { dengan }\end{array}$
menggunakan rumus sebagai berikut :

Lemak sartorial $(\%)=$ $\frac{\text { berat lemak sartorial }}{\text { berat badan }} \times 100 \%$ 


\section{Analisis Data}

Data yang diperoleh dianalisis dengan sidik ragam (ANOVA), apabila terdapat perbedaan dilakukan uji lanjut dengan menggunakan Ducan's multiple range test (DMRT) untuk melihat perbedaan antara perlakuan (Steel and Torrie, 1993).

\section{HASIL DAN PEMBAHASAN}

Data perlemakan ayam broiler terhadap pemberian tepung kulit pisang fermentasi (KPF) dengan menggunakan Neurospora crassa disajikan pada Tabel 4.

Tabel 4. Rataan perlemakan ayam broiler terhadap pemberian tepung kulit pisang fermentasi (KPF) dengan menggunakan Neurospora crassa pada umur 6-7 mingggu

\begin{tabular}{|c|c|c|c|c|c|}
\hline & $\begin{array}{l}\text { \% Berat } \\
\text { Lemak }\end{array}$ & $\begin{array}{l}\% \text { Berat } \\
\text { Lemak }\end{array}$ & $\begin{array}{l}\text { \% Berat } \\
\text { Lemak }\end{array}$ & $\begin{array}{l}\text { \% Berat } \\
\text { Lemak }\end{array}$ & $\begin{array}{l}\% \text { Berat } \\
\text { Lemak }\end{array}$ \\
\hline Perlakuan & Abdomen & Gizzard & Leher & Usus & Paha \\
\hline $\mathrm{P} 0$ & $1,29 \pm 0,43^{\mathrm{ab}}$ & $1,17 \pm 0,93^{b}$ & $0,42 \pm 0,20^{\mathrm{a}}$ & $0,24 \pm 0,09^{\mathrm{a}}$ & $0,21 \pm 0,30^{\mathrm{a}}$ \\
\hline $\mathrm{P} 1$ & $1,09 \pm 0,42^{\mathrm{ab}}$ & $0,48 \pm 0,22^{\mathrm{a}}$ & $0,50 \pm 0,27^{\mathrm{a}}$ & $0,21 \pm 0,09^{\mathrm{a}}$ & $0,18 \pm 0,15^{\mathrm{a}}$ \\
\hline $\mathrm{P} 2$ & $1,13 \pm 0,27^{\mathrm{ab}}$ & $0,40 \pm 0,14^{\mathrm{a}}$ & $0,39 \pm 0,27^{\mathrm{a}}$ & $0,17 \pm 0,04^{\mathrm{a}}$ & $0,17 \pm 0,10^{\mathrm{a}}$ \\
\hline P3 & $0,89 \pm 0,19^{\mathrm{a}}$ & $0,36 \pm 0,12^{a}$ & $0,25 \pm 0,10^{\mathrm{a}}$ & $0,19 \pm 0,05^{\mathrm{a}}$ & $0,18 \pm 0,12^{\mathrm{a}}$ \\
\hline P4 & $1,55 \pm 0,40^{\mathrm{b}}$ & $0,43 \pm 0,14^{\mathrm{a}}$ & $0,49 \pm 0,62^{a}$ & $0,21 \pm 0,15^{\mathrm{a}}$ & $0,36 \pm 0,30^{\mathrm{a}}$ \\
\hline
\end{tabular}

Ket: P0: kontrol tanpa pemberian KPF, P1; pemberian KPF 2,5 \%, P2: pemberian KPF 5\%, P3: pemberian KPF 7,5\%, P4: pemberian KPF $10 \%$.

Berdasarkan hasil analisis sidik ragam menunjukkan bahwa pemberian tepung kulit pisang fermentasi (KPF) dengan menggunakan Neurospora crassa berpengaruh tidak nyata $(\mathrm{P}>0,05)$ terhadap persentase lemak leher, persentase lemak paha persentase lemak usus dan berpengaruh nyata $(\mathrm{P}<0,05)$ terhadap persentase lemak abdomen dan lemak gizzard. Berdasarkan uji lanjut pada persentase lemak abdomen dengan pemberian KPF $10 \%$ (P4) $(1,55 \pm 0,40)$ berbeda sangat nyata dari perlakuan $\mathrm{P} 0, \mathrm{P} 1$, P2 dan P3. Persentase lemak abdomen lemak yang tertinggi ditemui pada $\mathrm{P} 4$, yang diduga karena ayam tidak mampu mendegradasi serat sehingga pertambahan lemak tetap terjadi. Menurut Holsheimer dan Veerkamp (1992) dan Syzka et al. (2012) bahwa pakan yang mengandung energi tinggi secara nyata meningkatkan kandungan lemak abdomen. Pada penelitian ini tampak bahwa lemak abdomen yang tertinggi terdapat pada $\mathrm{P} 4$, energi apabila dikonsumsi berlebih maka akan disimpan dalam bentuk lemak sebagai cadangan energi.

Persentase yang terendah terdapat pada perlakuan P3 $(0,89 \pm 0,19)$. Berdasarkan hasil penelitian Deaton et al. (1973) yang menyatakan bahwa bobot lemak abdominal cenderung meningkat dengan bertambahnya bobot badan, demikian sebaliknya. Bobot badan yang 
kecil disebabkan karena konsumsi ransum yang mengandung protein dari P3. Persentase lemak abdomen yang didapat pada penelitian ini cukup rendah, yaitu berkisar antara 0,89\%-1,09\%. Menurut Becker et al. (1979) menyatakan bahwa persentase lemak abdominal ayam broiler berkisar antara 0,73\% sampai 3,78\%. Pemberian KPF mampu menurunkan persentase lemak abdomen sebesar 31,0\% dan untuk perlakuan P1 sebesar 15,50\%, unuk perlakuan P2 12,40\%, dan untuk perlakuan P4 16,77\%.

Hasil analisis sidik ragam menunjukkan bahwa pemberian tepung kulit pisang fermentasi (KPF) dengan menggunakan Neurospora crassa berpengaruh nyata $(\mathrm{P}<0,05)$ terhadap lemak gizzard. Persentase lemak gizzard yang tertinggi ditemui pada P0, karena ayam tidak diberikan tepung kulit pisang fermentasi (KPF). Pada penelitian ini tampak bahwa lemak gizzard yang tertinggi terdapat pada P0. Persentase yang terendah terdapat pada perlakuan P3 $(0,36 \pm 0,12)$, ini lebih kecil jika dibandingkan dengan hasil penelitian Faber (2011) yaitu berkisar 0,90\%-1,28\% yang menggunkan ransum dengan tambahan ekstrak akar alang-alang. Persentase lemak gizzard pada ayam broiler umur 42 hari yaitu 0,48\%-0,68\% dari berat hidup (Rusydan, 2008).

Hasil analisis sidik ragam menunjukkan bahwa pemberian tepung kulit pisang fermentasi (KPF) dengan menggunakan Neurospora crassa berpengaruh tidak nyata $(\mathrm{P}>0,05)$ terhadap persentase lemak leher. Persentase tertinggi terdapat pada perlakuan P1 $(0,50 \pm 0,27)$ jika dibandingkan dengan kontrol maupun perlakuan P2, P3, dan P4, sedangkan persentase terendah terdapat pada perlakuan P3 $(0,25 \pm 0,10)$ dan mengalami peningkatan pada perlakuan $\mathrm{P} 2$ $(0,39 \pm 0,27)$ dan P4 $(0,49 \pm 0,62)$. Pada penelitian ini menunjuan bahwa persentase lemak leher yang didapat berkisar antara 0,25\%-0,50\% dan dapat diberikan hingga level 10\%. Jika dibandingkan dengan hasil penelitian sebelumnya seperti penelitian Rusydan (2008) mendapatkan persentase lemak leher broiler umur 42 hari adalah 0,80\%-1,09\%.

Hasil analisis sidik ragam menunjukkan bahwa pemberian tepung kulit pisang fermentasi (KPF) dengan menggunakan Neurospora crassa berpengaruh tidak nyata $(\mathrm{P}>0,05)$ terhadap persentase lemak penggantung usus. Persentase tertinggi terdapat pada perlakuan P0 $(0,24 \pm 0,09) \quad$ jika dibandingkan dengan perlakuan $\mathrm{P} 1, \mathrm{P} 2$, P3, dan P4, sedangkan persentase terendah terdapat pada perlakuan P2 $(0,17 \pm 004)$ dan mengalami peningkatan pada perlakuan $\mathrm{P} 3$ $(0,19 \pm 0,05) \quad$ dan P4 $(0,21 \pm 0,15)$. Penggunaan fermentasi kulit pisang jantan bisa diberikan hingga mencapai 10\%, karena tidak berbeda nyata antar perlakuan. Hasil analisis sidik ragam menunjukkan bahwa pemberian tepung kulit pisang fermentasi (KPF) dengan menggunakan Neurospora crassa berpengaruh tidak nyata $(\mathrm{P}>0,05)$ terhadap persentase lemak sartolial (paha). Persentase tertinggi terdapat pada perlakuan P4 $(0,36 \pm 0,30) \quad$ jika 
dibandingkan dengan perlakuan kontrol maupun P1, P2, dan P3, sedangkan persentase terendah terdapat pada perlakuan P2 $(0,17 \pm 0,10)$ dan mengalami peningkatan pada perlakuan $\mathrm{P} 1(0,18 \pm 0,15)$ dan P3 $(0,18 \pm 0,12)$. Persentase lemak paha yang diperoleh dalam penelitian ini berkisar antara 0,17\%-0,36\%. Jika dibandingkan dengan hasil penelian sebelumnya seperti penelitian yang dilakukan oleh Hazizan (2007) mendapatkan persentase lemak paha sebesar 0,35\%-0,44\%. Rusydan (2008) persentase lemak pahayang didapat yaitu 0,59\%-0,78\%. Berdasarkan data yang didapatkan oleh penelitian sebelumya bahwa lemak sartolial (paha) belum ditemukan standarnya dan masih bervariasi.

\section{KESIMPULAN}

Berdasarkan hasil penelitian kami dapat disimpulkan bahwa pemberian fermentasi tepung kulit pisang dengan menggunakan Neurospora crassa tidak menurunkan berat badan tetapi mengurangi lemak abdomen, lemak gizzard, lemak leher, lemak penggantung usus, lemak paha hingga level $10 \%$.

\section{UCAPAN TERIMAKASIH}

Terimakasih disampaikan kepada Kemristekdikti yang telah mendanai seluruh penelitian ini melalui Program Kreativitas Mahasiswa (PKM) tahun 2017. Terimakasih juga disampaikan kepada Prof. Dr. Ir. Yosi Fenita, MP yang telah membimbing dalam kegiatan penelitian ini.

\section{DAFTAR PUSTAKA}

Becker, W. A, J. V. Spencer, L. W. Minishand and J. A. Werstate. 1979. Abdominal and carcas fat in five broiler strain. Poult. Sci. 60:692-697.

Deaton, J. W, F. W. Reece, L. F. Kubena and J. D. May. 1973. Rearing Broiler Sexes Separate versus Combined. Poultry Sci. 52 : 16-19.

Elvien. 2010. Teknologi pengolahan pisang. Gramedia. Jakarta.

Faber, J. 2011. Penggunaan Ekstrak Akar Alang-alang (Imperata cyilindica) untuk Menurunkan Lemak pada Broiler. Skripsi. Jurusan Peternakan. Universitas Bengkulu. Bengkulu.

Fenita, J. U. Santoso, dan H. Prakoso. 2010. Pengaruh lumpur sawit fermentasi dengan neurospora crassa terhadap performan produksi dan kualitas telur. JITV 15(2):88-89.

Fenita, Y. U. Santoso, Nurmeiliasari dan D. Kaharuddin. 2013. Revitalisasi Lumpur Sawit Fermentasi dengan Suplementasi Ekstrak Daun Katuk dan Minyak Ikan Lemuru untuk Peningkatan Produksi, Produksi dan Kualitas Telur. Laporan Penelitian Hibah Penelitian Strategis Nasional. Fakultas Pertanian. Universitas Bengkulu. 
Hazizan, H. 2007. Pengaruh Pemberian Tepung Daun Sukun (Artocarpus communis) terhadap Akumulasi Lemak pada Broiler. Skripsi. Jurusan Peternakan. Universitas Bengkulu.

Heruwatno, K. D. Natawihardja, T. Widiastuti, dan C. Aisyah. 1993. Pengaruh Berbagai Tingkat Penggunaan Tepung Kulit Pisang Raja dalam Ransum terhadap Peformans Ayam Pedaging. Fakultas Peternakan. Universitas Padjadjaran. Bandung.

Holsheimer, J. P. And C. H.Veerkamp. 1992. Effect of dietary energy, protein and lysine content on performance and yields of two srains of male broiler chicks. Poultry Sci. 71:872-879.

Mirnawati, dan G. Ciptaan. 2001. Berat organ pisiologis ayam broiler pada ransum yang memakai kulit pisang batu (Musa brachiarpa) fermentasi. Jurusan Peternakan. Universitas Andalas. 13 (35) 2001. Institut Pertanian Bogor.

Nuraini. 2006. Potensi kapang Neurospora crassa dalam memproduksi pakan kaya beta-karoten dan pengaruhnya terhadap ayam pedaging dan petelur. Disertasi. Program Pasca Sarjana Universitas Andalas, Padang.

Nuraini Sabrina, dan S. A. Latif. 2008. Performa ayam dan kualitas telur yang menggunakan ransum mengandung onggok fermentasi dengan Neurospora crassa. Media Peternakan. 31: 195-202.

Rika, Z. 2012. Pemanfaatan Beta-Karoten dalam Tepung Kulit Pisang sebagai Pengganti Sebagian Jagung untuk Menghasilkan Telur Ayam Rendah Kolestrol. Skripsi. Departemen Ilmu Nutrisi dan Teknologi Pakan, Fakultas Peternakan, Institut Pertanian Bogor.

Rusydan, M. 2008. Pengaruh Penggunaan Tepung Akar Alang-alang (Imperata cyilindica) terhadap Penimbunan Lemak pada Broiler. Skripsi. Jurusan Peternakan. Universitas Bengkulu. Bengkulu.

Susilowati, I. 1997. Pengaruh limbah tetes dan urea pada pembuatan silase kulit pisang (Musa paradisiaca, L) terhadap kualitas silase. Skripsi. Sekolah Pertanian Tribhuana, Malang.

Sahin, E. H. dan Yardimci. 2009. Effects of kefir as a probiotic on growth performance and carcass characteristic in geese. J. Anim. Vet. 8:562-567.

Santoso, U., K. Tanaka, dan S. Ohtani. 1995. Effect of dried Bacillus subtilis culture on growth, body composition and hepatc lipogenic enzyme activity in female broiler chicks. Bri. J. Nutr., 74:523-529. 
Santoso, U., dan K. Tanaka. 2000. Pengaruh Umur terhadap Aktivitas Enzim Lipogenik di hati dan Akumulasi Lemak pada Ayam Broiler. Jurnal Ilmu Ternak dan Veteriner 6 (2): 89-93.

Santoso, U., K. Tanaka, S. Ohtani and M. Sakarida. 2001. Effect of fermented product from Bacillus subtilis on feed conversion efficiency, lipid accumulation and ammonia production in broiler chicks. Asian-Aust. Sci.14: 333337.

Sinurat, A. P. Supriyati, T. Pasaribu, H. dan Hamid. 1999. Fermentasi bungkil inti sawit secara substrat padat dengan menggunakan Aspergillus niger. Jurnal Ilmu Ternak Veteriner 3(3) : 165-170.

Syzka, M. G., R. D. Hery Supratman, dan Abun. 2012. Pengaruh Imbangan Energi dan Protein Ransum terhadap Bobot Karkas dan Bobot Lemak Abdominal Ayam Broiler Umur 3-5 Minggu. Fakultas Peternakan. Universitas Padjajaran. Bandung.

Wahyu, J. 2004. Ilmu Nutrisi Unggas. Gadjah Mada University Press. Yogyakarta 